\title{
The Moderating Role of Job Resourcefulness in the Impact of Work-Family and Family-Work Life Conflict on the Burnout Levels of Travel Agency Employees
}

\author{
Yilmaz Akgunduz*, Ovunc Bardakoglu**, Ceylan E. Alkan*** \\ Received: May 2015 | Accepted: August 2015
}

\begin{abstract}
The aim of this study is to determine the moderating role of job resourcefulness under the influence of work-family and family-work life conflict on the burnout levels of employees. In this context, a questionnaire was created using the Maslach Burnout Inventory (MBI), Work-Family Life Conflict, and Job Resourcefulness Scale. This survey was applied to travel agency employees in Izmir, Turkey, who were selected by using deliberate sampling method. At the end of the data collection period, 220 valid questionnaires were obtained. A hierarchical regression analysis was conducted to test the hypotheses based on the reliability and validity of the scales. Analysis results indicate that resourcefulness reduces detrimental effects of work-family conflict on emotional exhaustion and depersonalization. In addition results also indicate that job resourcefulness reduces detrimental effects offamily-work conflict on depersonalization. The implications of these results for future research are also discussed.
\end{abstract}

Key words: work-family conflict, family-work conflict, burnout, job resourcefulness, travel agency, human resources, Turkey.

\section{Introduction}

In today's tourism market due to the increase in stiff competition, employing skilled staff members who deliver high performance provides a great advantage for businesses (Licata, Mowen, Harris \& Brown, 2003: 257). For instance, in travel agencies, which are one of the most important type of business that operate in tourism sector, employees are obliged to communicate directly with customers and behave in a friendly manner throughout the sector. Quick changes in the market structure and increase in customer demands have forced travel agents to operate with more qualified

* Mersin University, Faculty of Tourism, Gastronomy and Culinary Arts Department, Mersin, Turkey, Corresponding author yilmazakgunduz@hotmail.com

** Dokuz Eylul University, Seferihisar Fevziye Hepkon Vocational School of Social Sciences, Tourism and Hotel Management Programme, Izmir, Turkey, E-mail: ovuncbardakoglu@hotmail.com

***Yasar University, Vocational School of Social Sciences Tourism and Hotel Management Programme, Izmir, Turkey, E-mail: ceylan.erdogan@yasar.edu.tr 
personnel and use their existing resources (Lam \& Zhang, 1999: 341). Therefore, from the perspective of these businesses, the most rational behavior is to employ staff who can use available resources effectively and have a high level of job resourcefulness (Iverson \& Deery, 1997: 71).

Despite of rapid technological development, the need for human labor in the tourism sector has not decreased. Although mechanization and automation have been partly incorporated into tourist products, service providers are still human being. The requirements to establish a close relationship with other customers, to work irregular hours, and to handle heavy workload at travel agencies because employees feel exhausted (Maslach \& Jackson, 1981: 100) and experiencing work-family conflicts arise from this role complexity (Greenhaus \& Beutell, 1985: 78).

According to the theory of spillover, what happens in the family or business can have effects in other environments. Negative effects lead to an increase in employees' feelings of burnout. The purpose of this study is to determine the impacts of work-family and family-work life conflicts on feelings of burnout and to identify the moderating role of job resourcefulness in this process. In this paper, firstly theoretical insights into burnout, work-family and familywork conflict, and job resourcefulness are discussed, and then the proposed hypotheses are presented. Accordingly, methods of and findings from the field researches which were conducted at travel agencies are described. In the last section, comparison of the findings and the literature, recommendations for travel agents, and limitations of the research are given.

\section{Literature review}

\section{Job Resourcefulness}

Along with the increase in competition, managers' expectations from their employees have changed in recent years, in particular it is best expressed in the popular phrase as 'Produce more with less' (Harris, Artis, Waters \& Licata 2006: 407). Staff members are expected to be resourceful, effective, and efficient in every stage of the business. The state of coping with obstacles on objectives of the job by using available resources in the best way is referred as job resourcefulness (Licata et al., 2003: 257).

Job resourcefulness results from the congruence between the characteristics of employees and the work environment (Ashill, Rod, Thirkell \& Corruthers, 2009: 338; Rod \& Ashill, 2009: $60)$. It has been observed that some employees work more efficiently and have higher capacity than the others. These differences have been associated mostly with individual's personality traits (Goldberg, 1990). Accordingly, individuals who have good communication skills, can quickly produce solutions, and maintain composure in the face of problems that have been observed to deliver high performance in their jobs (Benet-Martinez \& John, 1998: 730).

Job resourcefulness is evaluated in three different dimensions (Licata et al. 2003: 258): customer orientation (evaluation of personnel in terms of the services provided to the customer), staff members' evaluation of their own performance (self-evaluation), and managers' evaluations of personnel's performance. The effects of job resourcefulness are seen in employees' overall work performance and are closely associated with basic personality traits (Harris et al., 2006: 407). Therefore, the more the job is done compatible with the employee's personality traits, the higher the employee's efficiency is. Employees who are satisfied with the job (Meyer \& Allen, 1984) and work willingly have high levels of job resourcefulness and low levels of turnover intentions (Tett \& Meyer, 1993). High staff turnover in the tourism sector and the substantial costs to businesses from this situation (Harris et al., 2006), increase the importance of job resourcefulness. 


\section{Burnout}

Employees, who work constantly in direct contact with customers in service industry, must quickly find effective solutions to problems and this creates pressure on them. Moreover this leads to emergence of a feeling of burnout, as well as causing emotional self-indulgence and general bad feelings among employees (Maslach \& Jackson, 1981:100). The personality characteristics of employees (Goldberg, 1990) are also cause factors in the tendency towards burnout. Individuals with a low sense of self-efficacy are especially at risk of burnout. An increase in the feeling of emotional burnout and employee's belief that their emotional resources are depleted and their psychological state is worsening are the most important indicators of burnout (Maslach \& Jackson, 1981: 101).

Employees who become insensitive to what is going on around them (Leiter \& Maslach, 1988: 298) begin to experience problems in their relations with customers. Burnout starts with emotional exhaustion and progresses to depersonalization and finally a cause a decline in business success (Leiter \& Maslach, 1988: 299; Maslach \& Jackson, 1981: 105). When individuals do self-assessment, they see themselves as inadequate and unsuccessful (Maslach, Schaufeli \& Leiter, 2001: 400). While emotional exhaustion manifests as excessive exhaustion and reluctance (Leiter \& Maslach, 1988: 299) in the depersonalization state, the individual has lost the emotional ability to respond to events. When people start to perceive themselves as incompetent and inadequate at their jobs, a decline in personal accomplishment inevitably follows.

Burnout leads to emergence of unintended consequences for employees who began working with great hopes (Villavicencio-Ayub, Jurado-Cardenas \& Valencia-Cruz, 2015). A very small percentage of employees who are feeling exhausted can continue to do the same work whereas a large majority them think that a quitting from their work is the fastest and most effective solution. Therefore, burnout can be considered with job stress which is associated with job satisfaction, organizational commitment, and turnover intention (Maslach et al., 2001). Employee's, who experience emotional exhaustion, decrease their satisfaction level that they get from their job (Civilidag, 2014; Lee \& Ok, 2014). When an employee perceives that he/she is emotionally supported by their organizations, he/she gives up feeling of burnout (Yaghoubi, Pourghaz \& Toomaj, 2014). For this reason, managers should make effort to observe and find solutions for the troubles that are experienced by their employees as much as possible.

A research suggests that environmental factors (e.g., working conditions) have more influence on the emergence of burnout than personal characteristics (Leiter \& Maslach, 1988: 298). Additionally staff members who have problems with their colleagues and customers have been found to be closer to the feeling of burnout. Employees who think that they are emotionally exhausted adopt the mentality of seeking a quick getaway and convince themselves that the most rational solution is to quit (Parasuraman, 1992: 120).

\section{Work-Family and Family-Work Conflict}

Work and family life are the two major areas of individuals' lives (Netemeyer, Boles \& McMurrian, 1996: 400). The roles of individuals in these two fields does not always fit together, hence individuals experience conflicts. An individual who devotes more time to work, especially as a requirement of business life, reduces time that he/she spent with their family (Voydanoff, 1988: 479). Therefore if an employee starts to have problems in their work life, this will affect their family instantly and negatively (Turliuc \& Buliga, 2014). 
Work-family conflict is revealed by the incompatibility of some role demands arising from work and family (Greenhaus \& Beutell, 1985; Netemeyer, Brashear-Alejandro \& Boles, 2004: 49). Conflicts which arise from family demands and hinder work-related tasks are described as family-work conflict (Netemeyer et al., 1996: 40o). For example, time constraints and tension which is placed by family-related roles on work-related roles creates conflict. Work-family conflict, which is described as incongruity due to the simultaneous emergence of work and family roles (Parasuraman \& Simmers, 2001: 551), has three dimensions: time, tension, and behavior (Greenhaus \& Beutell, 1985). Time-based conflict (Rotondo, Carlson \& Kincaid, 2003) is a difficulty to fulfill one role while fulfilling others (work or family), tension-based conflict is exposure to stress in an area that affects performance in other areas, and behavior-based conflict is the incongruence of behaviors that is required by roles which are in different areas. If organizations adjust their human resources policies in a way that employees feel relaxed in their family order to prevent work-family conflicts, rates of employee withdrawal will decrease (Nohe \& Sonntag, 2014).

From the perspective of businesses, work-family and family-work conflict reduces individual productivity in the workplace and imposes a financial burden on the organization (Netemeyer et al., 2004: 57). When individuals lose their control on the challenges that they face in workplace, problems that over flow from the job, will effect negatively to individual's level of well-being, and significantly reduce individual's quality of life (Greenhaus, Bedeian \& Mossholder, 1987). Factors such as long, inflexible working hours, shift work, and presence of preschool age children and elderly relatives in the family create conflicts for employees (Greenhaus \& Beutell, 1985). The emergence of conflict directly relates to emotions, such as job satisfaction, burnout, turnover intention, psychological distress, and private life dissatisfaction (Netemeyer et al., 1996: 400). As an individual's sense of conflict becomes more severe, the adverse effects will increase (Greenhaus \& Beutell, 1985). Studies on gender and conflict show that genders have different ways of experiencing conflicts (Voydanoff, 1988: 749). It has been found that, while duties and responsibilities in the workplace are more prominent in the foreground for men, responsibilities at home are more important to women. Whether employees are married or not is quite affective in having conflicts (Gamor, Amissah \& Boakye, 2014). Because indefinite working times encountered in especially hotel business, this business is one of the most important premises of becoming evident in work-family conflicts. If managers realize that employees have work-family conflict and try to find plausible solutions for them, employees will start to feel better and increase their efficiency (Winefield, Boyd \& Winefield, 2014).

\section{Development of Hypotheses}

Work-family conflict, which is regarded as a form of inter-role conflict, occurs as a result of incompatibility between the role assumed as member of an organization and the role assumed as member of a family (Mete, Ünal \& Bilen, 2014). Impact of work-family conflict on the behaviors of employees in organizations can be explained by spillover theory which is developed by Staines (1980). According to this theory, experiences of employees inside and outside the job environment have similarities. Both positive and negative overflow can be experienced. Tensions, pressures, and concerns within the family or the organization reveal negative emotions, while feelings, such as excitement, happiness, and development, reveal positive emotions (Onderoglu, 2010). Employees' family-work or work-family conflicts affect other employees and can lead to negative feelings among employees. Studies have shown that work-family life conflicts cause organizational problems, such as turnover intention (Carikci \& Celikkol, 
2009; Karatepe \& Uludag, 2008; Karatepe, 2009; Netemeyer et al., 2004) and burnout among employees (Cleveland et al., 2007; Karatepe, Sokmen, Yavas \& Babakus, 2010). Based on the literature and spillover theory, hypotheses1 and 2 are proposed.

H1. Employees' work-family conflicts positively affect their feelings of burnout.

H1a. Employees' work-family conflicts positively affect feelings of emotional burnout.

H1b. Employees' work-family conflict positively affects feelings of personal accomplishment.

H1c. Employees' work-family conflicts positively affect feelings of depersonalization.

$\mathrm{H} 2$. Employees' family-work conflicts positively affect their feelings of burnout.

H2a Employees' family-work conflicts positively affect feelings of emotional burnout.

$\mathrm{H}_{2}$ b. Employees' family-work conflicts positively affect feelings of personal accomplishment.

H2c. Employees' family-work conflicts positively affect feelings of depersonalization.

Even if there is a reduction in resources that is available in organization, employees are expected to deliver same performance (Licata et al., 2003, p. 258). Employees with high levels of job resourcefulness produce better results with fewer resources and they can easily handle challenges that arise from conflicts of family and work roles (Hobfoll, 1989). Therefore, as a positive concept, job resourcefulness, is expected to reduce problems that might arise within an organization, such as feelings of burnout. Rod and Ashill (2009) determined that employees with high job resourcefulness, which is a personal trait, have lower levels of burnout. Based on the results of previous studies, if employees have job resourcefulness, their feelings of burnout are expected to be low. Hypothesis 3 is proposed in this context.

H3. Employees' job resourcefulness negatively affects feelings of burnout.

H3a. Employees' job resourcefulness negatively affects feelings of emotional burnout.

$\mathrm{H}_{3}$ b. Employees' job resourcefulness negatively affects feelings of personal accomplishment.

$\mathrm{H}_{3 \mathrm{c}}$. Employees' job resourcefulness negatively affects feelings of depersonalization.

Karatepe (2011) found that employees with higher job resourcefulness have lower levels of work-family conflict; additionally Kim, Shin \& Umbreit (2007) reported that employees which have personal trait of compliance have lower levels of burnout. Employees' job resourcefulness is expected to have moderating role in the intensification of feelings of burnout by work-family and family-work conflict; therefore, hypotheses 4 and 5 are proposed.

H4. Job resourcefulness has a moderating role in the effect of employees' work-family conflict on feelings of burnout.

$\mathrm{H}_{4}$ a. Job resourcefulness has a moderating role in the effect of employees' work-family conflict on feelings of emotional burnout.

H4b. Job resourcefulness has a moderating role in the effect of employees' work-family conflict on feelings of personal accomplishment.

H4c. Job resourcefulness has a moderating role in the effect of employees' work-family conflict on feelings of depersonalization.

$\mathrm{H}_{5}$. Job resourcefulness has a moderating role in the effect of employees' family-work conflict on feelings of burnout.

$\mathrm{H}_{5} \mathrm{a}$. Job resourcefulness has a moderating role in the effect of employees' family -family conflict on feelings of emotional burnout. 


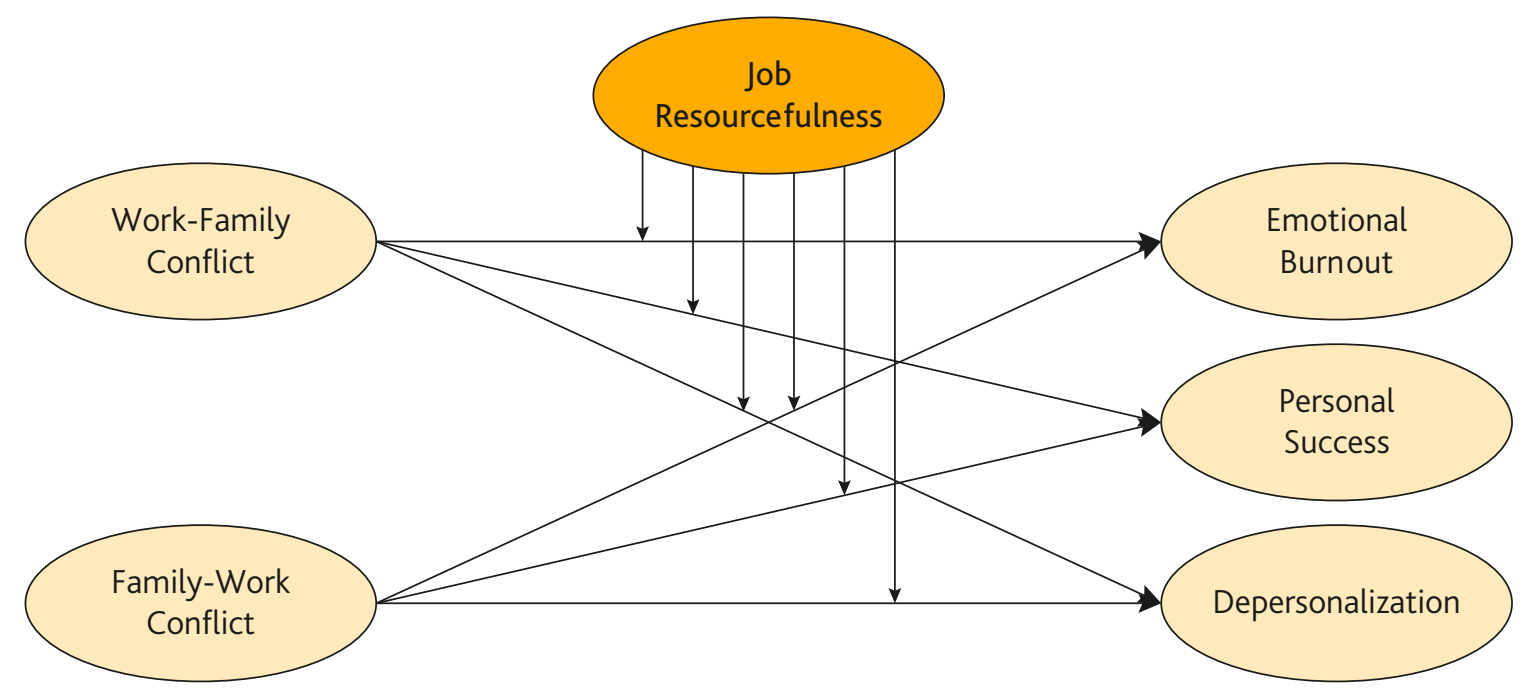

Figure 1. Research model

$\mathrm{H}_{5}$ b. Job resourcefulness has a moderating role in the effect of employees' family -family conflict on feelings of personal accomplishment.

$\mathrm{H}_{5 \mathrm{c}}$. Job resourcefulness has a moderating role in the effect of employees' family -family conflict on feelings of depersonalization.

\section{Methods}

\section{Population and sample}

This study was applied to employees that work at travel agencies which operate in Izmir, Turkey. According to the records of Association of Turkish Travel Agencies (TURSAB), 374 travel agencies operate in Izmir. Data were collected from Alsancak, Konak, Karsiyaka, and Cankaya districts, which have high work flow. Intentional (decisional) sampling method was used in the study. Data were collected from travel agencies that operate in Alsancak (77 agencies), Konak (64 agencies), Karsiyaka (39 agencies), and Cankaya (26 agencies) districts. Population size was determined to be 618 based on an average of 3 employees per agency due to the lack of exact information about number of employees that work at the agencies. The population size for this study was calculated using the notation $\mathrm{n}=238$, a $95 \%$ confidence interval, and a $5 \%$ margin of error for the main population (Hair et al., 2010). By the end of the data collection from 21 April-20 June 2014, 220 valid questionnaires were collected.

\section{Data Collection Tools}

MBI was used to determine burnout feelings of employees. MBI which was developed by Maslach (1982) has been applied in many sectors including tourism. MBI has 3 dimensions (emotional burnout, depersonalization, and personal accomplishment) and 22 items (Maslach, 1982). A fivepoint likert type scale was used in the study. The scale was composed of expressions that range from 1 (never) to 5 (always). A version of MBI which was developed by Türkmen and Pelit (2008) 
was used in the study. Work-Family Conflict Scale was developed by Netenmeyer et al. (1996) and adapted by Efeoglu (2006). The adapted version of the scale was used in this study. The scale has two dimensions (work-family and family-work conflict), with five items each.

The Job Resourcefulness Scale which was developed by Licata et al. (2003: 269) has one dimension and four items. After the authors of this study translated the scale in Turkish, it was evaluated by three academicians in the field of organizational behavior. The scale was also modified based on the results of pilot test. The items of the Work-Family Conflict Scale and the Job Resourcefulness Scale were expressed in 5 point likert-type scale that range from 1 (disagree) to 5 (strongly agree).

In addition, the survey included two closed-ended items to determine participants' gender and educational status and three open-ended items to determine their age, department, and length of time at their current employer.

\section{Results}

Table 1, which reports participants' demographic characteristics, shows that $61 \%$ are women (133), $71 \%$ have undergraduate and graduate degrees, $62 \%$ (130) are 30 years old or younger, $64 \%$ (134) have work experience of 6 years or more, and 52\% (106) work in ticket sales.

Table 1. Demographic characteristics of participants

\begin{tabular}{|c|c|c|c|c|c|}
\hline & $n=220$ & $\%$ & & $n=220$ & $\%$ \\
\hline \multicolumn{3}{|l|}{ Gender } & \multicolumn{3}{|l|}{ Work Time } \\
\hline Women & 133 & 61 & 5 years or less & 74 & 36 \\
\hline Men & 86 & 39 & 6 years and above & 134 & 64 \\
\hline \multicolumn{3}{|l|}{ Education } & \multicolumn{3}{|l|}{ Department } \\
\hline Primary school & 1 & 1 & Sales & 106 & 52 \\
\hline Secondary school & 1 & 1 & Conferences & 6 & 3 \\
\hline High school & 49 & 22 & Switchboard & 1 & 1 \\
\hline Associate's degree & 61 & 28 & In-coming & 6 & 3 \\
\hline Bachelor's degree & 92 & 43 & Travel advice & 27 & 13 \\
\hline Master's degree & 11 & 5 & Marketing & 10 & 5 \\
\hline \multicolumn{3}{|l|}{ Age } & Management & 15 & 7 \\
\hline 30 years old or younger & 130 & 62 & Accounting & 13 & 6 \\
\hline 31 years old or older & 78 & 38 & Operations & 18 & 9 \\
\hline
\end{tabular}

The convergent and discriminant validity of the overall measurement quality is employed through confirmatory factor analysis (CFA) (Anderson \& Gerbing, 1988). It is necessary for the standardized loads not to be below 0.50 or over 0.70 ; and $t$ values should be over 1.96 (Hair, Black, Babin \& Anderson, 2010). Therefore, internal consistency reliability was checked through composite reliability using the cut-off value of 0.70 (Hair et al., 2010). Three items from emotional burnout, two items from personal accomplishment, and one item from the depersonalization measurement were excluded from the analysis.

The final results of CFA revealed the following fit statistics: $X^{2}=836.50 ; \mathrm{df}=390 \mathrm{X}^{2} / \mathrm{df}=2.14$; root mean square error of approximation $=0.066$; goodness - of- - it index $=0.88$; adjusted goodness of fit index $=0.84$; parsimony goodness of fit index $=0.66$; comparative fit index $=0.97$; incre- 
mental fit index $=0.97$; relative fit index $=0.95$; parsimony normed fit index $=0.81$; non-normed fit index $=0.96$; normed fit index $=0.96$; root mean square residual $=0.044$; and standardized root mean square residual $=0.053$. The results indicated a reasonable fit of the four-factor model to the data. As shown in Table 2, the results collectively showed that there was evidence of convergent validity (Hair et al., 2010).

Table 2. CFA results

\begin{tabular}{|c|c|c|c|c|}
\hline & $\begin{array}{l}\text { Standardized } \\
\text { loading }\end{array}$ & t-value & AVE & CR \\
\hline \multicolumn{3}{|l|}{ Emotional Burnout (6 items) } & 0.55 & 0.88 \\
\hline I feel emotionally drained from my work. & - & - & - & - \\
\hline I feel frustrated by my job. & - & - & - & - \\
\hline I feel burned out from my work. & - & - & - & - \\
\hline Working with people all day is really a strain for me. & 0.83 & 14.63 & & \\
\hline I feel fatigued when I get up in the morning and have to face another day on the job. & 0.73 & 12.15 & & \\
\hline I feel used up at the end of the workday. & 0.77 & 13.14 & & \\
\hline I feel I am working too hard on my job. & 0.64 & 10.07 & & \\
\hline I feel like I am at the end of my rope. & 0.64 & 10.17 & & \\
\hline Working with people directly puts too much stress on me & 0.80 & 13.81 & & \\
\hline \multicolumn{3}{|l|}{ Personal Accomplishment (6 items) } & 0.51 & 0.86 \\
\hline I deal effectively with the problems of my customers.* & - & - & - & - \\
\hline I feel I am positively influencing other people's lives through my work.* & - & - & - & - \\
\hline I feel exhilarated after working closely with my customers.* & 0.74 & 12.02 & & \\
\hline I can easily create a relaxed atmosphere with my customers.* & 0.70 & 11.03 & & \\
\hline I feel very energetic. & 0.54 & 7.96 & & \\
\hline I have accomplished many worthwhile things in this job.* & 0.87 & 16.91 & & \\
\hline I can easily understand how my recipients feel about things & 0.60 & 9.13 & & \\
\hline In my work, I deal with emotional problems very calmly.* & 0.79 & 13.09 & & \\
\hline \multicolumn{3}{|l|}{ Depersonalization (5 items) } & 0.56 & 0.84 \\
\hline \multicolumn{5}{|l|}{ I feel I treat some customers as if they were impersonal objects } \\
\hline I have become more callous towards people since I took this job. & 0.87 & 12.37 & & \\
\hline I worry that this job is hardening me emotionally. & 0.64 & 10.01 & & \\
\hline I do not really care what happens to some customers. & 0.71 & 11.82 & & \\
\hline I feel customers blame me for some of their problems. & 0.76 & 14.80 & & \\
\hline \multicolumn{3}{|l|}{ Work-Family Conflict } & 0.61 & 0.89 \\
\hline The demands of my work interfere with my home and family life. & 0.75 & 12.48 & & \\
\hline $\begin{array}{l}\text { The amount of time my job takes up makes it difficult to fulfill my family } \\
\text { responsibilities. }\end{array}$ & 0.84 & 14.68 & & \\
\hline Things I want to do at home do not get done because of the demands my job puts on me. & 0.83 & 14.32 & & \\
\hline My job produces strain that makes it difficult to fulfill family duties. & 0.81 & 14.01 & & \\
\hline Due to work-related duties, I have no make changes to my plans for family activities. & 0.65 & 10.28 & & \\
\hline \multicolumn{3}{|l|}{ Family-Work Conflict } & 0.59 & 0.88 \\
\hline The demands of my family or spouse interfere with work-related activities. & 0.69 & 11.05 & & \\
\hline I have to put off doing things at work because of demands on my time at home. & 0.77 & 13.01 & & \\
\hline
\end{tabular}




\begin{tabular}{|c|c|c|c|c|}
\hline & $\begin{array}{l}\text { Standardized } \\
\text { loading }\end{array}$ & t-value & AVE & CR \\
\hline $\begin{array}{l}\text { Things I want to do at work do not get done because of the demands of my family or } \\
\text { spouse. }\end{array}$ & 0.81 & 13.79 & & \\
\hline $\begin{array}{l}\text { My home life interferes with my responsibilities at work such as getting to work on } \\
\text { time, accomplishing daily tasks, and working overtime. }\end{array}$ & 0.79 & 13.51 & & \\
\hline Family-related strain interferes with my ability perform job-related duties. & 0.78 & 13.11 & & \\
\hline \multicolumn{3}{|l|}{ Job Resourcefulness } & 0.61 & 0.86 \\
\hline When it comes to completing tasks at my job I am very clever and enterprising & 0.81 & 13.55 & & \\
\hline I am able to make things happen in the face of scarcity at my job & 0.85 & 14.57 & & \\
\hline At my job, I think I am a fairly resourceful person. & 0.75 & 12.17 & & \\
\hline On the job I am clever and inventive in overcoming barriers. & 0.72 & 11.66 & & \\
\hline
\end{tabular}

Notes: All loadings are significant at the 0.01 level. AVE, average variance extracted; $C R$, composite reliability; - , dropped during CFA. ${ }^{*}$ Reversed scored.

Model fit statistics: $X^{2}=836.50 \mathrm{df}=390 \mathrm{X}^{2} / \mathrm{df}=2.14 \mathrm{AGFI}=0.84 ; G F I=0.88 ; C F I=0.97 ; \mid F I=0.97 ; R M S E A=0.066$.

In this study, the discriminant validity was also assessed. Fornell \& Lacker (1981) suggest that the AVE value of every construct should be greater than the squared correlation coefficient with other constructs. Table 3 confirms the discriminant validity.

Table 3. Discriminant validity

\begin{tabular}{|l|r|r|r|r|r|r|}
\hline & \multicolumn{1}{c|}{1} & \multicolumn{1}{c|}{$\mathbf{2}$} & \multicolumn{1}{c|}{$\mathbf{3}$} & \multicolumn{1}{c|}{$\mathbf{5}$} & \\
\hline Emotional Burnout & 0.55 & & & & & \\
\hline Personal accomplishment & 0.55 & 0.51 & & & & \\
\hline Depersonalization & 0.40 & 0.27 & 0.56 & & & \\
\hline Work-Family Conflict & 0.04 & 0.11 & 0.29 & 0.61 & & \\
\hline Family-Work Conflict & 0.37 & 0.17 & 0.13 & 0.08 & 0.59 & 0.25 \\
\hline Job Resourcefulness & 0.21 & 0.08 & 0.15 & 0.12 & 0.61 \\
\hline
\end{tabular}

Note:

The numbers in the cells of diagonal line are AVE;

The numbers in the cells of off-diagonal line are squared correlation coefficients of one factor with another factor;

Denotes significance level of 0.01 .

The means, standard error values, reliability, and correlation values of burnout, job resourcefulness, and work-family and family-work conflict, which were analyzed in the research, are presented in Table 4.

Table 4. Descriptive analyses

\begin{tabular}{|c|c|c|c|c|c|c|c|c|}
\hline & Mean & SD & 1 & 2 & 3 & 4 & 5 & 6 \\
\hline 1. Emotional Burnout & 2.813 & 0.830 & 1 & & & & & \\
\hline 2. Personal Accomplishment & 3.815 & 0.599 & 0.74 & 1 & & & & \\
\hline 3. Depersonalization & 2.291 & 0.917 & 0.63 & 0.52 & 1 & & & \\
\hline 4. Job Resourcefulness & 3.956 & 0.661 & -0.20 & -0.33 & -0.54 & 1 & & \\
\hline 5. Work-Family Conflict & 2.911 & 1.002 & 0.61 & 0.41 & 0.36 & -0.29 & 1 & \\
\hline 6. Family-Work Conflict & 2.212 & 1.105 & 0.46 & 0.28 & 0.39 & -0.34 & 0.50 & 1 \\
\hline
\end{tabular}

Note. Denotes significance level of 0.01; SD is standard deviation 
In the correlation analysis, emotional burnout was found to have significant negative relationship with job resourcefulness $(\mathrm{r}=0.20 \mathrm{p}<0.01)$; positive relationship with work-family conflict $(\mathrm{r}=0.61 \mathrm{p}<0.01)$, and family-work conflict $(\mathrm{r}=0.46 \mathrm{p}<0.01)$. Personal accomplishment have significant negative relationship with job resourcefulness $(\mathrm{r}=0.33 \mathrm{p}<0.01)$; positive relationship with work-family conflict $(\mathrm{r}=0.41 \mathrm{p}<0.01)$, and family-work conflict $(\mathrm{r}=0.28 \mathrm{p}<0.01)$. Depersonalization have significant negative relationship with job resourcefulness $(r=0.54 p<0.01)$; positive relationship with work-family conflict $(\mathrm{r}=0.36 \mathrm{p}<0.01)$, and family-work conflict $(\mathrm{r}=0.39$ $\mathrm{p}<0.01)$. Additionally, job resourcefulness was found to have significant negative relationship with work-family conflict $(\mathrm{r}=0.29 \mathrm{p}<0.01)$, and family-work conflict $(\mathrm{r}=0.34 \mathrm{p}<0.01)$.

The results of the hierarchical regression analysis conducted to test the proposed hypotheses are summarized in Table 5,6 , and 7 .

Table 5. Regression analysis results on the moderator role of job resourcefulness

\begin{tabular}{|c|c|c|c|c|c|c|c|c|c|}
\hline \multicolumn{5}{|c|}{ Emotional Burnout } & \multicolumn{5}{|c|}{ Emotional Burnout } \\
\hline \multirow{2}{*}{\multicolumn{2}{|c|}{ Independent Variables }} & \multicolumn{3}{|c|}{ Number of Levels } & \multirow{2}{*}{\multicolumn{2}{|c|}{ Independent Variables }} & \multicolumn{3}{|c|}{ Number of Levels } \\
\hline & & \multirow{2}{*}{$\begin{array}{l}1 . \\
0.538^{*}\end{array}$} & \multirow{2}{*}{$\begin{array}{l}2 . \\
0.551^{*}\end{array}$} & \multirow{2}{*}{\begin{tabular}{l|}
3. \\
$0.958 *$ \\
\end{tabular}} & & & \multirow{2}{*}{\begin{tabular}{l|}
1. \\
$0.414^{*}$ \\
\end{tabular}} & \multirow{2}{*}{$\begin{array}{l}2 . \\
0.410 \\
\end{array}$} & \multirow{2}{*}{$\begin{array}{l}3 . \\
-0.305\end{array}$} \\
\hline 1 & Work-Family Conflict & & & & 1 & Family-Work Conflict & & & \\
\hline II & Job Resourcefulness & & $-0.153 *$ & $-0.121 *$ & II & Job Resourcefulness & & $-0.23 *$ & $-0.127 *$ \\
\hline III & $\begin{array}{l}\text { Work-Family Conflict* } \\
\text { Job Resourcefulness }\end{array}$ & & & $-0.483^{*}$ & III & $\begin{array}{l}\text { Family-Work Conflict* } \\
\text { Job Resourcefulness }\end{array}$ & & & 0.085 \\
\hline \multicolumn{2}{|l|}{$\mathrm{F}$} & 88.743 & 49.311 & 33.743 & \multicolumn{2}{|l|}{$\mathrm{F}$} & 45.138 & 22.548 & 15.302 \\
\hline \multicolumn{2}{|l|}{$\mathrm{R}$} & 0.538 & 0.559 & 0.565 & \multicolumn{2}{|l|}{$R$} & 0.414 & 0.415 & 0.419 \\
\hline \multicolumn{2}{|c|}{$\mathrm{R}^{2}$ at each step } & 0.289 & 0.312 & 0.319 & \multicolumn{2}{|c|}{$R^{2}$ at each step } & 0.172 & 0.172 & 0.175 \\
\hline \multicolumn{2}{|c|}{$\Delta \mathrm{R}^{2}$} & 0.286 & 0.306 & 0.320 & \multicolumn{2}{|c|}{$\Delta R^{2}$} & 0.107 & 0.166 & 0.164 \\
\hline \multicolumn{2}{|c|}{ Sig } & 0.000 & 0.000 & 0.000 & \multicolumn{2}{|l|}{ Sig } & 0.000 & 0.000 & 0.000 \\
\hline
\end{tabular}

${ }^{*} p$-Value $<0.01$

The finding in Table 5 show that although work-family conflict and family-work conflict have a significantly positive effect on employees' emotional burnout, job resourcefulness has a significantly negative effect on employees' emotional burnout. Therefore $\mathrm{H}_{1} \mathrm{a}, \mathrm{H} 2 \mathrm{a}$, and $\mathrm{H}_{3} \mathrm{a}$ are supported.

As reported in Table 5, the interaction of work-family conflict and job resourcefulness significantly negative effect on employees' emotional burnout $(\beta=-0.483 \mathrm{p}<0.01)$. There is a significant increment in $\mathrm{R}^{2}$ of the model $\left(\Delta \mathrm{R}^{2}=0.32 \mathrm{p}<0.05\right)$. Therefore, Hypothesis 4 a is supported. In addition, according to Table 6 , the interaction of family-work conflict and job resourcefulness does not significant effect on employees' emotional burnout $(\beta=-0.085, p>0.05)$. Therefore, Hypothesis $5 \mathrm{a}$ is not supported. 
Table 6. Regression analysis results on the moderator role of job resourcefulness

\begin{tabular}{|c|c|c|c|c|c|c|c|c|c|}
\hline \multicolumn{5}{|c|}{ Personal Accomplishment } & \multicolumn{5}{|c|}{ Personal Accomplishment } \\
\hline \multirow{2}{*}{\multicolumn{2}{|c|}{ Independent Variables }} & \multicolumn{3}{|c|}{ Number of Levels } & \multirow{2}{*}{\multicolumn{2}{|c|}{ Independent Variables }} & \multicolumn{3}{|c|}{ Number of Levels } \\
\hline & & \multirow{2}{*}{$\frac{1 .}{0.466^{*}}$} & \multirow{2}{*}{$\frac{2 .}{0.483 *}$} & \multirow{2}{*}{$\frac{3 .}{0.567^{*}}$} & & & \multirow{2}{*}{$\frac{1 .}{0.374^{*}}$} & \multirow{2}{*}{$\frac{2 .}{0.360 *}$} & \multirow{2}{*}{$\frac{3 .}{-0.298 *}$} \\
\hline I & Work-Family Conflict & & & & I & Family-Work Conflict & & & \\
\hline II & Job Resourcefulness & & $-0.184 *$ & $-0.139 *$ & II & Job Resourcefulness & & $-0.170 *$ & $-0.358 *$ \\
\hline III & $\begin{array}{l}\text { Work-Family Conflict* } \\
\text { Job Resourcefulness }\end{array}$ & & & -0.101 & III & $\begin{array}{l}\text { Family-Work Conflict* } \\
\text { Job Resourcefulness }\end{array}$ & & & 0.585 \\
\hline \multicolumn{2}{|l|}{$\mathrm{F}$} & 60.420 & 36.262 & 24.101 & \multicolumn{2}{|l|}{$\mathrm{F}$} & 35.514 & 18.371 & 13.371 \\
\hline \multicolumn{2}{|l|}{$\mathrm{R}$} & 0.466 & 0.500 & 0.501 & \multicolumn{2}{|l|}{$R$} & 0.374 & 0.381 & 0.396 \\
\hline \multicolumn{2}{|c|}{$\mathrm{R}^{2}$ at each step } & 0.217 & 0.250 & 0.251 & \multicolumn{2}{|c|}{$R^{2}$ at each step } & 0.140 & 0.145 & 0.157 \\
\hline \multicolumn{2}{|c|}{$\Delta R^{2}$} & 0.213 & 0.244 & 0.240 & \multicolumn{2}{|c|}{$\Delta \mathrm{R}^{2}$} & 0.136 & 0.137 & 0.145 \\
\hline \multicolumn{2}{|c|}{ Sig } & 0.000 & 0.000 & 0.000 & \multicolumn{2}{|l|}{ Sig } & 0.000 & 0.000 & 0.000 \\
\hline
\end{tabular}

${ }^{*} p$-Value $<0.01$

The finding in Table 6 show that although work-family conflict and family-work conflict have a significantly positive affect on employees' personal accomplishment, job resourcefulness has a significantly negative effect on employees' personal accomplishment. Therefore $\mathrm{H} 1 \mathrm{~b}, \mathrm{H}_{2} \mathrm{~b}$, and $\mathrm{H}_{3} \mathrm{~b}$ are supported. In addition, according to Table 6 neither the interaction of work-family conflict and job resourcefulness, nor the interaction of family-work conflict and job resourcefulness significantly affect employees' personal accomplishment. Therefore, Hypothesis $4 \mathrm{~b}$, and $5 \mathrm{~b}$ are not supported.

The finding in Table 7 show that although work-family conflict and family-work conflict have a significantly positive affect on employees' depersonalization, job resourcefulness has a significantly negative effect on employees' depersonalization. Therefore $\mathrm{H}_{1} \mathrm{c}, \mathrm{H}_{2} \mathrm{c}$, and $\mathrm{H}_{3} \mathrm{c}$ are supported. As indicated in Table 7, both interaction of work-family conflict and job resourcefulness $(\beta=0.522 p<0.01)$, and the interaction of family-work conflict and job resourcefulness $(\beta=0.176 \mathrm{p}<0.01)$ significantly and positively affect employees' depersonalization. Therefore, Hypothesis $4 \mathrm{C}$ and $5 \mathrm{C}$ are supported. These results indicate that job resourcefulness reduces detrimental effects of work-family and family-work conflict on employees' depersonalization.

Table 7. Regression analysis results on the moderator role of job resourcefulness

\begin{tabular}{|c|c|c|c|c|c|c|c|c|c|}
\hline \multicolumn{5}{|c|}{ Depersonalization } & \multicolumn{5}{|c|}{ Depersonalization } \\
\hline \multirow{2}{*}{\multicolumn{2}{|c|}{ Independent Variables }} & \multicolumn{3}{|c|}{ Number of Levels } & \multirow{2}{*}{\multicolumn{2}{|c|}{ Independent Variables }} & \multicolumn{3}{|c|}{ Number of Levels } \\
\hline & & \multirow{2}{*}{$\frac{1 .}{0.382 *}$} & \multirow{2}{*}{$\frac{2 .}{0.362 *}$} & \multirow{2}{*}{$\frac{3 .}{0.827^{*}}$} & & & \multirow{2}{*}{$\begin{array}{l}1 . \\
0.202^{*}\end{array}$} & \multirow{2}{*}{$\frac{2 .}{0.265^{*}}$} & \multirow{2}{*}{$\frac{3 .}{0.433^{*}}$} \\
\hline I & Work-Family Conflict & & & & I & Family-Work Conflict & & & \\
\hline II & Job Resourcefulness & & $-0.232 *$ & $-0.476^{*}$ & II & Job Resourcefulness & & $-0.316 *$ & $-0.403^{*}$ \\
\hline III & $\begin{array}{l}\text { Work-Family Conflict* } \\
\text { Job Resourcefulness }\end{array}$ & & & $0.522^{*}$ & III & $\begin{array}{l}\text { Family-Work Conflict* } \\
\text { Job Resourcefulness }\end{array}$ & & & $0.176^{*}$ \\
\hline \multicolumn{2}{|l|}{$\mathrm{F}$} & 37.272 & 26.998 & 18.899 & \multicolumn{2}{|l|}{$\mathrm{F}$} & 9.311 & 17.194 & 11.513 \\
\hline \multicolumn{2}{|l|}{$\mathrm{R}$} & 0.382 & 0.446 & 0.456 & \multicolumn{2}{|l|}{$\mathrm{R}$} & 0.202 & 0.370 & 0.371 \\
\hline \multicolumn{2}{|c|}{$\mathrm{R}^{2}$ at each step } & 0.146 & 0.199 & 0.208 & \multicolumn{2}{|c|}{$\mathrm{R}^{2}$ at each step } & 0.041 & 0.137 & 0.138 \\
\hline \multicolumn{2}{|c|}{$\Delta R^{2}$} & 0.142 & 0.192 & 0.197 & \multicolumn{2}{|c|}{$\Delta \mathrm{R}^{2}$} & 0.037 & 0.129 & 0.126 \\
\hline \multicolumn{2}{|c|}{ Sig } & 0.000 & 0.000 & 0.000 & \multicolumn{2}{|c|}{ Sig } & 0.000 & 0.000 & 0.000 \\
\hline
\end{tabular}

${ }^{*} p$-Value $<0.01$ 


\section{Discussion}

The aim of this study is to determine the effect of work-family conflict and family-work conflict on employee burnout (emotional burnout, personal accomplishment, and depersonalization) and moderating role of job resourcefulness in this effect on travel agency employees. The present study contributes to the literature in particular by investigating job resourcefulness as a moderator role of effects of work-family conflict and family-work conflict on burnout via data which were gathered from travel agencies of Izmir.

Results demonstrate that work-family conflict and family-work conflict increase travel agencies employees' emotional burnout, personal accomplishment, and depersonalization. This finding corresponds with previous studies (Adam et al., 2008; Jensen, 2014; Lingard \& Francis, 2006; Wang, Liu, Wang \& Wang, 2012). It can be argued that effects of work-family conflict on burnout feelings cause employees to feel tired, exhausted, and helpless in the work environment because time and labor is needed to fulfill their job requirements to create some problems. To derive maximum benefit from employees, businesses sometimes assign employees over workload which might adversely affect their family life. Employees, who strive to accomplish these tasks, cannot fulfill their responsibilities to their families. However, when considered in the long run, it is natural that employees will face numerous adversities when they cannot fulfill their family responsibilities due to their workload or job responsibilities. Behaviors of employees whose jobs cause problems in their family lives are negatively affected by this dynamic. Therefore, when determining employees' duties and responsibilities, managers should assign employees a level of tasks and responsibilities that will not adversely affect their family life. Therefore this approach will allow the businesses to benefit more from its employees in the long run.

In this study family-work conflict was found to increase levels of employee emotional burnout, personal accomplishment, and depersonalization. It can be seen that employees who struggle to fulfill family responsibilities feel tired, exhausted, and sometimes helpless at their jobs. The findings support previous studies in the literature (Burke \& Greenglass, 2001; Karatepe et al., 2010; Lin, Huang, Yang \& Chiang, 2014; Rupert, Stevanovi \& Hunley, 2009). Managers should arrange working hours of employees the way that employees could fulfill their responsibilities to their families as a social and physiological being; likewise they should also take account of their special situations. Therefore this approach might help to reduce family-work conflict and the reduced family-work conflict will help to decrease employees' feelings of burnout.

Evidence from this study indicates that organizational success is effective in decreasing exhaustion level of travel agency employees. Business success of employees is directly related with their work efficiency and their capabilities of coping with problems arising in this process (Ashill, Rod, Thirkell \& Corruthers, 2009). Therefore assigning tasks to employees who are appropriate for their abilities will increase organizational success hence decrease level of exhaustion of employees. Findings of this study indicate that work-family conflict increase emotional exhaustion and depersonalization and decrease organizational success. Depending on the evidences regarding directing effect of organizational success, it is certain that workfamily and family-work conflict increase emotional exhaustion and depersonalization on the contrary organizational success weakens this negative effect. For this reason, if managers increase employees' work success, it is possible that managers would decrease work-family and family-work conflicts, emotional exhaustion and depersonalization. It is clear that in order to increase employees' business success, managers should maintain training and coaching applications autonomously and give feedbacks to employees. 


\section{Limitations and Future Research}

The sample of this study is limited with travel agency employees in Izmir. The required sample size was collected however the preferred method of data collection and sampling method are the limitations of the study. To reduce negative impact of the limitations, future studies should use quota sampling method that takes into account distribution of departments at travel agencies. Additionally they should also support survey results with in-depth interviews, and recruit a larger sample from other tourism businesses.

This study used the MBI, Work-Family Conflict Scale, and Job Resourcefulness Scale. Participants were able to assess themselves only in this context. In future studies, investigating variables such as burnout, work-family conflict, and job resourcefulness, along with personality traits and core self-evaluation, could determine the relationships between the variables in question and the influence of participants' evaluation of their personality characteristics on their feelings of burnout. Additionally, future studies could test different hypotheses by including statements about how the variables in question affect employees' job performance and turnover intention.

\section{References}

Adam, S., Zsuza, G., \& Susanszky, E. (2008). Physician burnout in Hungary a potential role for work-family conflict. Journal of Health Psychology, 13(7), 847-856.

Anderson, J. C., \& Gerbing, D.W. (1988). Structural equation modeling in practice: A review and recommended two-step approach. Psychological Bulletin, 103, 411-423.

Ashill, N. J., Rod, M., Thirkell, P., \& Corruthers, J. (2009). Job resourcefulness, symptoms of burnout and service recovery performance: An examination of call center frontline employees. Journal of Service Marketing, 23(5), 338-350.

Benet-Martinez, V., \& John, O. P. (1998). Los cinco grandes across cultures and ethnic groups: Multitrait multi method analyses of the big five in Spanish and English. Journal of Personality and Social Psychology, 75(3), 729-750.

Burke, R. J., \& Greenglass, E. R. (2001). Hospital restructuring, work-family conflict and psychological burnout among nursing staff. Psychology and Health, 16(5), 583-594.

Carikci, İ. H., \& Celikkol, Ö. (2009). The effects of work - family conflict on organizational commitment and intention to leave. Journal of Süleyman Demirel University Institue of Social Sciences, 2009/1(9), 153-170.

Chen, F. F., \& Kao, Y. L. (2012). Moderating effects of work engagement and job tenure on Burnout-performance among flight attendants. Journal of Air Transport Management, 25, 61-63.

Civilidag, A. (2014). Hotel employees' mobbing, burnout, job satisfaction and perceived organizational support: a research on hospitality in Turkey. European Scientific Journal, 10(35), 1-22.

Cleveland, J. N., O’Neill, J. W., Himelright, J. L., Harrison, M. M., Crouter, A. C., \& Drago, R. (2007). Work and family issues in the hospitality industry: Perspectives of entrants, managers, and spouses. Journal of Hospitality and Tourism Research, 31(3), 275-298.

Efeoglu, İ. E. (2006). The effects of work family conflict on job stress, job satisfaction and organizational commitment: A study in the pharmaceutical industry. Unpublished master's thesis,. Çukurova University, Adana. 
Fornell, C., \& Larcker, D. (1981). Evaluating structural equation models with unobservable variables and measurement error. Journal of Marketing Research, 18, 39-50.

Gamor, E., Amissah, E., \& Boakye, K. (2014). Work-family conflict among hotel employees in Sekondi-Takoradi Metropolis, Ghana. Tourism Management Perspectives, 12, 1-8.

Goldberg, L. R. (1990). An alternative "description of personality": The big-five factor structure. Journal of Personality and Social Psychology, 59(6), 1216-1229.

Greenhaus, J. H., \& Beutell, N. J. (1985). Sources of conflict between work and family roles. The Academy of Management Review, 10(1), 76-88.

Greenhaus, J. H., Bedeian, A. G., \& Mossholder, K. W. (1987). Work experiences, job performance, and feelings of personal and family well-being. Journal of Vocational Behavior, 31(7), 200-215.

Hair, J, F. Jr., Black, W. C., Babin, B. J., \& Anderson, R. E. (2010). Multivariate Data Analysis (7th ed.). Upper Saddle River, NJ: Prentice Hall.

Harris, E. G., Artis, A. B., Waters, J. H., \& Licata, J. W. (2006). Role stressors service worker job resourcefulness and job outcomes: An empirical analyses. Journal of Business Research, 59(4), 407-415.

Hobfoll, S. E. (1989). Conservation of resources. American Psychologist, 44(3), 513-524.

Iverson, R. D., \& Deery, M. (1997). Turnover Culture in the hospitality industry. Human Resource Management Journal, 7(4), 71-82.

Jensen, M. T. (2014). Exploring business travel with work-family conflict and the emotional exhaustion component of burnout as outcome variables: The job demands-resources perspective. European Journal of Work and Organizational Psychology, 23(4), 497-510.

Karatepe, O. M. (2009). An investigation of the joint effects of organizational tenure and supervisor support on work-family conflict and turnover intentions. Journal of Hospitality and Tourism Management, 16, 73-81.

Karatepe, O. M. (2011). Job resourcefulness as a moderator of the work-family conflict job satisfaction relationship: A study of hotel employees in Nigeria. Journal of Hospitality and Tourism Management, 18, 10-17.

Karatepe, O. M., Uludag, O. (2008). Affectivity, Conflicts in the Work-Family Interface, And Hotel Employee Outcomes. International Journal of Hospitality Management, 27, 30-41.

Karatepe, O. M., Sokmen, A., Yavas, U., \& Babakus, E. (2010). Work-family conflict and burnout in frontline service jobs: direct, mediating and moderating effects. Ekonomika A Management, 4, 61-73.

Kim, H. J., Shin, K. H., Umbreit, W. T. (2007). Hotel job burnout: The role of personality characteristics. Hospitality Management, 26, 421-434.

Lam, T., \& Zhang, H. Q. (1999). Service quality of travel agents: The case of travel agents in Hong Kong. Tourism Management, 20(3), 341-349.

Lee, J., \& Ok, C. (2014). Reducing burnout and enhancing job satisfaction: Critical role of hotel employees' emotional intelligence and emotional labor. International Journal of Hospitality Management, 31, 1101-1112.

Leiter, M. P., \& Maslach, C. (1988). The impact of interpersonal environment on burnout and organizational commitment. Journal of Organizational Behavior, 9(4), 297-308.

Licata, J. W., Mowen, J. C., Harris, E. G., \& Brown, T. J. (2003). On the trait antecedents and outcomes of service worker job resourcefulness: A hierarchical model approach. Journal of Academy of Marketing Science, 31(3), 256-271. 
Lin, Y. S, Huang, W. S., Yang, C. T., \& Chiang, M. J. (2014). Work-leisure conflict and its associations with well-being: The roles of social support, leisure participation and job burnout. Tourism Management, 45, 244-252.

Lingard, H., \& Francis, V. (2006). Does a supportive work environment moderate the relationship between work-family conflict and burnout among construction professionals?. Construct. Manage. Econ., 24, 185-196.

Maslach, C. (1982). Burnout: The Cost of Caring, Prentice Hall: Englewood Cliffs, NJ.

Maslach, C., Jackson, S.E. (1981). The measurement of experienced burnout. Journal of Occupational Behavior, 2, 99-113.

Maslach, C., Schaufeli, W.B., \& Leiter, M.P. (2001). Job burnout. Annual Review of Psychology, $52,397-422$

Mete, M., Ünal, Ö.F., \& Bilen, A. (2014). Impact of work-family conflict and burnout on performance of accounting professionals. Social and Behavioral Sciences, 131, 264-270.

Meyer, J. P., \& Allen, N. J. (1984). Testing the 'side-bet theory' of organizational commitment: Some methodological considerations. Journal of Applied Psychology, 69(3), 372-378.

Netemeyer, R. G., Boles, J. S., \& McMurrian, R. (1996). Development and validation of work-family conflict and family-work conflict scales. Journal of Applied Psychology, 81(4), 400-410.

Netemeyer, R. G., Brashear-Alejandro, T., \& Boles, J. S. (2004). A cross-national model of job-related outcomes of work role and family role variables: A retail sales context. Journal of the Academy of Marketing Science, 32(1), 49-60.

Nohe, C., \& Sonntag, K. (2014). Work-family conflict, social support, and turnover intentions: A longitudinal study. Journal of Vocational Behavior, 85, 1-12.

Onderoğlu, S. (2010). The relationships between perception of organizational justice work family conflict and perceived organizational support. Unpublished master's thesis. Ankara University, Ankara.

Parasuraman, S. (1992). Predicting turnover intentions and turnover behavior: A multivariate analysis. Journal of Vocational Behavior, 21(1), 111-121.

Parasuraman, S. S., \& Simmers, C. A. (2001). Type of employment, work-family conflict and well-being: A comparative study. Journal of Organizational Behavior, 22, 551-568.

Türkmen, F. \& Pelit, E. (2008). The level of burnout of hotel employees: A study into the employees at domestic and foreign hotel chains. Gazi Üniversitesi İktisadi ve İdari Bilimler Fakültesi Dergisi, 10(1), 117 - 139.

Prentice, C., Chen, P. J., \& King, B. (2013). Employee performance outcomes and burnout following the presentation-of-self in customer-service contexts. International Journal of Hospitality Management, 35, 225- 236.

Rod, M., \& Ashill, N.J. (2009). Symptoms of burnout and service recovery performance the influence of job resourcefulness. Managing Service Quality, 19(1), 60-84.

Rotondo, D. M., Carlson, D. S., \& Kincaid, J. K. (2003). Coping with multiple dimensions of work-family conflict. Personnel Review, 32(3), 275-296.

Rupert, P. A., Stevanovic, P., \& Hunley, H. A. (2009). Work-family conflict and burnout among practicing psychologists. Professional Psychology: Research and Practice, 40(1), 54-56.

Staines, G. L. (1980). Spillover versus compensation: A review of the literature on the relationship between work and nonwork. Human Relations, 33(2), 111-129.

Tett, R. P., \& Meyer, J. P. (1993). Job satisfaction, organizational commitment, turnover intention and turnover: Path analyses based on meta-analytic findings. Personnel Psychology, 46(2), 259-293. 
Turliuc, M., \& Buliga, D. (2014). Work-family conflict and job and family satisfaction. the mediating role of cognitions. Procedia - Social and Behavioral Sciences, 159, 105-109.

Villavicencio-Ayub, E., Jurado-Cardenas, S., \& Valencia-Cruz, A. (2015). Work engagement and occupational Burnout: Its relation to organizational socialization and Psychological resilience. Journal of Behavior, Health \& Social Issues, 6(2), 45-55.

Voydanoff, P. (1988). Work role characteristics, family structure demands and work/family conflict. Journal of Marriage and Family, 50(3), 749-761.

Wang, Y., Liu, L., Wang, J., \& Wang, L. (2012). Work-family conflict and burnout among Chinese doctors: the mediating role of psychological capital. Journal of Occupational Health, 54(3), 232-240.

Winefield, H., Boyd, C., \& Winefield, A. (2014). Work-family conflict and well-being in university employees. The Journal of Psychology, 148(6), 683-697.

Yaghoubi, M., Pourghaz, A., \& Toomaj, G. (2014). Study of perceived organizational support's relationship with job burnout. International Journal of Academic Research in Business and Social Sciences, 4(6). 315-324. 